\title{
The Construction of Human Destiny Community in the Post-epidemic Age
}

\author{
Fan $\mathrm{Wu}^{1}$ \\ ${ }^{1}$ College of Marxism, China Jiliang University, Hangzhou, 310018, China \\ *Corresponding author. Email: w13735526010@163.com
}

\begin{abstract}
This paper mainly discusses how to accelerate the construction of human community with a shared future under the influence of the COVID-19. In view of this problem, the paper mainly adopts the literature analysis method and the history analysis method to analyse and solve the problem. Through the analysis of General Secretary Xi Jinping's related exposition on COVID-19, this paper analyses the important influence of the construction of human community with a shared future on the Chinese people. Put forward an important way for the world countries to accelerate the construction of human community with a shared future. The security of international environment plays an important role in safeguarding the development of world economy and politics. China's anti-epidemic achievements have also proved to the world that the scientific nature of the concept of human community with a shared future put forward by General Secretary Xi Jinping, and the necessity to accelerate the construction of such community.
\end{abstract}

Keywords: New crown pneumonia outbreak, Human destiny community, Revelation, Meaning.

\section{INTRODUCTION}

2019 is a very extraordinary year. The outbreak of new coronary pneumonia was sudden, and China bore the brunt of the virus. Under the catalysis of time, the new crown virus rages into every country in the world. The new crown pneumonia epidemic has become a global biological crisis. It is not the first time that countries around the world have experienced hundreds or even thousands of years of development. Science and technology as a catalyst for the industrial revolution, the world continues to progress, but also accelerated the integration of the world into an indivisible whole. In the event of a global crisis, no one can stay away. Therefore, in order to promote the sustainable development of the world, all countries should get rid of the negative nationalist sentiment, put down the ideological prejudice, unite and cooperate, fight against the epidemic situation regardless of the past, and strive to build a community of human destiny.

Since the outbreak of the new crown pneumonia, under the strong leadership of the Communist Party of China, the people of all ethnic groups in the country have been fighting against the epidemic, not afraid of difficulties and obstacles, into this war without smoke, and have made remarkable achievements. In the process of fighting the epidemic, the tenacious Chinese people show the Chinese spirit incisively and vividly, and let us witness the impeccable strength of the Chinese nation. The Chinese people use their own actions to gather the majestic power to promote the great rejuvenation of the Chinese nation, showing the socialist institutional advantages and the spirit of the Chinese people's unremitting struggle. Most importantly, in the process of uniting against the epidemic, the Chinese people's self-confidence and national identity and sense of belonging have been greatly enhanced. Always adhere to the scientific guidance of Xi Jinping's socialist thought with Chinese characteristics in the new era.

\section{ALWAYS ADHERE TO THE XI JINPING'S THOUGHT ON SOCIALISM WITH CHINESE CHARACTERISTICS FOR THE NEW ERA}

Under the leadership of the CPC Central Committee, however, the people of the whole country responded positively to General Secretary Xi Jinping's strong call for "epidemic situation is an order, prevention and control is a responsibility ". 
After the outbreak of new crown pneumonia, the Party Central Committee quickly issued a series of measures to combat the epidemic. From the establishment of the Central Leading Group for the Response to the Epidemic, the dispatch of the Central Steering Group to Hubei, to the general requirements of firm confidence, solidarity, scientific prevention and control, and precise implementation of measures, under the centralized and unified leadership of the CPC Central Committee with Comrade Xi Jinping as the core, the people of all ethnic groups throughout the country have always adhered to the people's war, the overall war, and the war against the epidemic, guided by the socialist ideology with Chinese characteristics in the new era of Xi Jinping [1]. Up to now, the people of the whole country have achieved periodic results in fighting the epidemic. In order to consolidate this hard-won achievement, General Secretary Xi Jinping has put forward the requirement of normalization of epidemic prevention and control. We must soberly realize the complexity and severity of the epidemic situation at home and abroad, and it is urgent to fight the epidemic situation. The people should always bear in mind the supremacy of life, turn their thoughts into actions, unswervingly consolidate the achievements of epidemic prevention and control, and make the situation of epidemic prevention and control continue to improve.

Do not forget the original ideals and aspirations, brave mission, the Chinese people have maintained a positive and brave attitude and responsibility from beginning to end. In the face of the epidemic, the Chinese people will not choose to escape, but face it positively. Under the guidance of Xi Jinping's socialist thought with Chinese characteristics in the new era, we should consciously turn "four consciousness" and "four self-confidence" into ideals and beliefs. In the fight against the epidemic in action to effectively achieve "two maintenance". Take epidemic prevention and control as their own responsibility and obligation to contribute to the victory of the virus.

\section{IT INSPIRES THE CHINESE PEOPLE'S NATIONAL CONFIDENCE AND IDENTITY}

The Chinese nation is a weathered nation, and today it still stands among the nations of the world, which is inseparable from the strength of our great national spirit. The great national spirit is the source and base of our confidence and the important driving force of a nation's progress. Chinese excellent traditional culture is the deep accumulation of the Chinese people's spiritual pursuit for thousands of years and the unique spiritual symbol of the Chinese nation and the Chinese people. Influenced by the excellent Chinese traditional culture, the Chinese people have formed a different way of thinking and behavior, supporting the Chinese nation for five thousand years [1].

In the struggle against the epidemic, our people's self-confidence and strong feelings of patriotism are intertwined, and the people of the whole country are United and United to overcome the difficulties. Chinese people you have me, I have your self-consciousness deepened, formed a strong joint force, carry forward the national spirit of unity and courage of the Chinese nation, and actively fight against the epidemic. The unity of the Chinese people shows the spirit of the Chinese nation not afraid of difficulties, and the sense of human destiny community has long been deeply rooted in the hearts of the Chinese people. China's achievements in fighting the epidemic have proved to the world its determination to overcome the epidemic, and it has also declared to the world that only unity and cooperation must be invincible. At all times, the Chinese people can achieve the same breath, common destiny, showing the profound cultural heritage of the concept of human destiny community, but also showing the world the patriotic spirit of the Chinese people to move forward bravely and the excellent Chinese tradition of the people's life and the people's interests first. It also shows that the Chinese people have the national spirit of undefeated and undefeated.

Patriotism is the core of the Chinese spirit and the most precious spiritual wealth of the Chinese people. The strong patriotism in the hearts of the Chinese people is a powerful spiritual motive force for the people to safeguard national independence and national dignity. 1 Since the outbreak of the epidemic, people from all walks of life throughout the country have been engaged in the struggle against the epidemic, inspiring the Chinese people's strong combat effectiveness. Under the centralized and unified leadership of the Communist Party of China and the call of patriotic feelings, the Chinese people do their best to fight against the clock. We can see that researchers and first-line medical staff have made great sacrifices and contributions to the development of vaccines and the race between life and time to fight death and to protect the life and health of the Chinese people. The virus knows no borders and is the common enemy of the 
people of the world. In the face of the epidemic, faith is more precious than gold. General Secretary Xi Jinping pointed out that "the Chinese nation has experienced a lot of tribulations in history, but has never been crushed, but the more frustrated and braveconstantly growing in the tribulation, rising from the tribulation."[1] After thousands of years of hardships and hardships, the Communist Party of China was born in internal and external troubles, with the brand of war, with the spirit of hard struggle, tenacious struggle to survive in the gap, and finally won [2]. Our party is a self-perfection, self-development, continuous progress of the Marxist party, will never stop. In the face of the epidemic, as long as we grasp the detailed prevention and control work, facing the difficulties, we will certainly be able to turn the crisis into an opportunity to make the people's lives re-energize.

We should remember history and learn from it. Patriotism, as the only spiritual link between the Chinese people and the Chinese nation, provides a source of strength for the Chinese people to form strong cohesion and centripetal force, and promotes the continuous progress of Chinese society. This epidemic situation has greatly stimulated the Chinese people's inner national self-confidence and national identity. We should constantly enrich the connotation of the Chinese national spirit, constantly sublimate, and realize the great rejuvenation of the Chinese nation at an early date.

Since the 18th National Congress of the Party, General Secretary $\mathrm{Xi}$ Jinping has put forward the scientific idea of constructing the community of human destiny based on the value goal of the people of the world yearning for a better life. The global spread of the new crown pneumonia has made it clear that humanity is a solidarity. In dealing with this global crisis, the world should pay more attention to the harmony between man and nature. This is also a thought-provoking major issue for the world. At present, China is working with people all over the world to win the epidemic prevention and control war.

\section{THE SCIENTIFIC CONNOTATION OF HUMAN COMMUNITY WITH A SHARED FUTURE}

Since the concept of human destiny community was put forward, its connotation has been enriched with the progress of society and the development of the times. The concept of human destiny community embodies the common destiny of all mankind under the background of deepening globalization. It reflects the global spirit of prosperity, loss, prosperity, loss.

Globalization has become an irreversible trend in the world and an irresistible historical trend. This phenomenon is inevitable and undesirable against the trend. The development of globalization is inevitable in history. Globalization is a double-edged sword, which is both an opportunity and a challenge for world development. No one can stand out. Be alone. In order to promote the common development of economy, we must form a community of destiny with shared responsibility and results. From beginning to end, China adheres to the principle of universal benefit, win-win and sharing, and warmly welcomes all countries in the world to take the ride of China's development to promote the development and progress of the world. China has always actively advocated the construction of a community of human destiny. Make the fate of all countries in the world with the common, blessing and disaster depend on each other. The solidarity of the peoples of the world is in line with the overall value pursuit of all mankind.

The construction of human destiny community needs to have the common ideal belief, the value pursuit as the guidance, without the common ideal foundation, the destiny community can not talk about. Our country advocates the human destiny community in the cultural value pursuit aspect, manifests for the harmony but the difference, eclectic. It is very different from the views of western countries. We recognize the diversity of world cultures, promote equal and inclusive cultural exchange attitudes and foster common values. Our country always pursues the values of seeking common ground while reserving differences in order to expand and consolidate the consensus of mankind. For the exchange and integration of human civilization to build an indestructible bridge.

\section{OBSTACLES IN THE CONSTRUCTION OF HUMAN COMMUNITY WITH A SHARED FUTURE}

Since the outbreak of new crown pneumonia, China has always practiced the concept of human destiny community in its actions, and China is increasingly close to the center of the world stage. In the fight against the epidemic every moment shows China's great power style and responsibility. At the special summit of the leaders of the G20 to deal with the outbreak of the new crown pneumonia, General Secretary Xi Jinping stressed in particular:" What the international 
community needs most is to strengthen confidence, make concerted efforts, unite to deal with it, strengthen international cooperation in an all-round way, rally a strong joint effort to overcome the epidemic, and join hands to win this human struggle against major infectious diseases."[2] However, as the global situation of the new crown pneumonia epidemic continues to be grim, nationalism in a few Western countries has risen in an attempt to stigmatize China, putting all responsibility for the spread of the epidemic on China.1In fact, democratic sentiment does not begin today, but the epidemic provides a new opportunity for nationalism to rise. In responding to the epidemic, China made bold decisions, took active and effective measures, and actively cooperated with other countries to fight the epidemic. In this process, China has shown its due great power and made indelible contributions to the world. Some Western countries have not shown their due attitude of unity and cooperation, but have used the epidemic to make some anti-China remarks in an attempt to discredit China's image. These acts reflect the mindset of certain people and the so-called narrow nationalism [3].

China's achievements in the fight against the epidemic are obvious to all, and can not be slandered or vilified. U.N. Secretary-General Guterres said the Chinese people made great sacrifices to prevent and control the epidemic and that "they are contributing to all mankind".[4] Fukuyama, a Japanese-American scholar who has issued the theory of "the end of history ", also believes that China's anti-epidemic action is" the most successful non-western model ". In the face of the new crown virus, the common enemy of all mankind, the fate of mankind is increasingly closely linked [3]. In the current crisis, the political brand of the epidemic and the creation of an ideological bias "virus" in the international community can not solve any problems. Stigma China is not only not in line with international justice, but also not conducive to cooperative anti-epidemic [3].

In the long river of history, the Chinese people have fought the virus more than once, no matter which sudden invisible war is the warning of nature to mankind, warning people to live in harmony with nature. This alarm bell reminds people that human beings are a whole of solidarity. Only by adhering to the concept of human destiny community can the international community be invincible and invincible. Only by adhering to the concept of the community of human destiny, abandoning the narrow nationalist concept of putting personal interests above national interests, resolving disputes through dialogue and communication among countries, resolving differences through consultation, putting aside ideological prejudices, keeping watch and helping each other, and forming an inextricable joint force, can we win the final victory in this global war. Only by working together can we effectively deal with global challenges and crises, and the development of the international community can maintain a good situation of lasting and peace.

The new crown virus pneumonia epidemic is the common challenge facing all mankind. Today, mankind has already formed you and me, and I have your destiny community, People face the same risks and challenges. For human beings, the security of the international environment is common, the economic interests are common, and the responsibilities of all countries are common. Because the fate of all of us is connected. In the face of the epidemic, we need a scientific and rigorous attitude, play a spirit of unity and cooperation, rather than blindly prevarication, mutual hatred. Only as close collaborators and practitioners can we win the final victory in fighting the epidemic.

\section{REVELATION OF COVID-19 EPIDEMIC OO THE CONSTRUCTION OF HUMAN COMMUNITY WITH A SHARED FUTURE}

\subsection{Strengthen Economic Regulation and Promote Global Economic Recovery}

Today's world is a world of economic globalization, the economies of various countries blend with each other, the outbreak of the epidemic has caused a huge impact on the world economic system. In order to maintain the normal operation of the world economy, General Secretary Xi Jinping pointed out at the G20 leaders' summit:" countries should work together to increase macroeconomic policy resilience and prevent the world economy from falling into recession. It is necessary to implement effective fiscal and monetary policies, maintain the stability of the global financial market and the supply chain of the global industrial chain."[5] As a result of the epidemic, some countries have fallen into economic regression, unemployment has increased, people's lives can not guarantee stability, 
resulting in the world economy into a stagnant crisis [1]. To this end, China has taken the lead in introducing various economic policies to help enterprises tide over difficulties, promote the orderly resumption of production by enterprises, and maintain a steady recovery of the economy. Practice has proved that a series of measures taken by our country are very effective. China will continue to actively promote the establishment of a healthy and orderly economic governance system, build a healthy and stable international environment, increase ties with countries around the world, and provide the strongest impetus and support for the world economic recovery.

\subsection{Enhance International Political TMutual rust and Create a New Situation of Anti-epidemic}

Political contradictions and conflicts in the world have always existed, even intensified. Because of the ideological differences between countries, hegemonism and power politics still exist. Always threaten the peace and development of the world. General Secretary Xi Jinping stressed:" We must respect each other, consult on an equal footing, resolutely abandon the cold war mentality and power politics, and take a new path of dialogue without confrontation, partnership and non-aligned countries." When the outbreak first broke out in China. More than 170 countries and organizations have extended condolences and support to China in various ways [6]. But at the same time, some countries try to stigmatize China because of ideological conflicts and prejudices, and think that the new crown virus is a Chinese virus. We should clearly realize that any act of denigrating China and damaging its reputation is essentially a slander of Chinese politics, and we should maintain zero tolerance for such acts. The concept of human destiny community is put forward by our country, and all countries should correctly understand the profound connotation contained in the concept. In the face of the epidemic, all countries should put aside ideological prejudice, establish good international political trust, and jointly promote a new situation of international joint anti-epidemic response on the premise of mutual respect and equal consultation.

\subsection{Deepen Cultural Exchanges Among Countries and Create Global Cultural Environment}

In the action of global epidemic prevention and control, the cultural exchange between China and the world is becoming more and more frequent. General Secretary Xi Jinping pointed out:" We should seek wisdom from different civilizations, draw nutrition, provide spiritual support and spiritual comfort for people, and work together to solve the challenges facing mankind."[7] Chinese culture is broad and profound, and there are words such as "together in the wind and rain" and "together in the same boat" in our traditional culture [1]. In the process of anti-epidemic, countries all over the world have spared no effort to help and support China. There are also slogans such as "exotic mountains and rivers, the same wind and moon," unity and victory," which reflect the blend of Chinese excellent traditional culture and world culture. The concept of human destiny community advocated by Xi Jinping itself is the product of the combination of "harmony" and "unity of nature and man" in Chinese traditional culture and the concept of harmonious coexistence between man and nature in Marxism, which embodies the common pursuit of value. This also provides the possibility for the construction of the world cultural system. It also shows that China is willing to carry out cultural exchanges and sharing with all countries in the world, and also actively absorbs nutrients from the cultures of all countries in the world. Culture is pluralistic, treat culture, China has always maintained the attitude of seeking common ground while reserving differences, culture is not high or low, we should stop cultural hegemonism in time, resist the wrong cultural infiltration and value output. Actively advocate the construction of an equal and harmonious international cultural exchange environment, and add help to the further exchange and development of world culture in the future.

\subsection{Build a Global Health Governance System and Share Research Achievements on Anti-epidemic}

The new crown pneumonia epidemic is a global crisis, but also a people's war. The virus is raging, warning of the urgency and necessity of building a sound global health governance system. The international community should take active and effectivemeasures to carry out extensive international 
health cooperation to combat the epidemic. China is o-nstantly exporting Chinese power to the world in the prevention and control of the global epidemic situation. At an important juncture in the fight against the epidemic, China has accelerated the upgrading of the medical and health industry chain, concentrated manpower and material resources to speed up the production of masks, protective clothing and other materials, and provided them to all countries in the world. As always, practice the concept of human health community. In terms of epidemic information, Chinahas taken the lead in publishing virus genesequencing data to the world. In the case of WHO, China has maintained a leading position, actively played a leading role, and coordinated the operation of various health organizations. At the same time actively advocated the establishment of a sound public health governance system. In the construction of public health, China will continue to follow the principle of co-construction and sharing, promote the establishment of an informationsharing mechanism on the epidemic situation at theinternational level, and improve the exchange platform for epidemic prevention experts from various countries. The most advanced anti-epidemic ideas and the most effective anti-epidemic programsare pushed to the world, contributing Chinese wisdom and Chinese programs to the world's anti-epidemic cause.

\section{CONCLUSIONS}

Since the concept of human community with a shared future was put forward, it has been questioned by the outside world. Practice has proved that the concept of human community with a shared future put forward by General Secretary Xi Jinping is consistent. Through the precipitation of time and the proof of practice, more and more people have affirmed and supported the concept of human community with a shared future. The international community has also given high praise to it. In the smoke-free war against the COVID-19, the Chinese people gave the most powerful response to the outside world with their own actions, fully demonstrated the theoretical value and significance of the human community with a shared future under the background of the special era. Only by adhering to the concept of human community with a shared future can we defeat the common enemy of mankind. At the present stage, the world has entered the post-epidemic era, but the epidemic situation is still continuing, and the anti-epidemic situation is still grim. All countries must uphold the concept of human community with a shared future, strengthen cooperation and anti-epidemic, and create a harmonious and secure international environment for the people of the world.

\section{REFERENCES}

[1] Dickinson. Fighting the New Crown Pneumonia Epidemic $[\mathrm{N}]$. has greatly stimulated national identity and sense of belonging Qinghai Daily ,2020-04-13(010). (In Chinese)

[2] Xi Jinping," Working Together against the Epidemic -- A Speech at the Extraordinary Summit of G20 Leaders ", People's Daily, 27 March 2020, 2nd edition. (In Chinese)

[3] Chen Ting. Construction of Community of Human Destiny under the Test of Epidemic [J]. Front Line 2021(01). (In Chinese)

[4] China shows the image of a responsible big country with practical actions-the international community actively supports China in winning the war of prevention and control of the epidemic, People's Daily, February 26, 2020, 3rd edition. (In Chinese)

[5] Xi Jinping. Fight the epidemic and fight the hard times: a speech at the G20 summit [M]. of leaders Beijing: people's Publishing House. (In Chinese)

[6] Zhang Lv. A probe into the Community of Human Destiny in the New era of $\mathrm{Xi}$ Jinping [D]. Southwest University, 2018. (In Chinese)

[7] Xi Jinping. Persisting in Promoting the Construction of a Community of Human Destiny Beijing: central Literature Publishing House, 2018:81253. (In Chinese) 